\title{
Characterization of the diversity of peri-urban farms in the metropolis of Casablanca in Morocco to facilitate their agroecological transition to more sustainable food systems
}

\author{
Fatiha Hakimi
}

Department of Production, Protection and Plant Biotechnology, Hassan II Institute of Agronomy and Veterinary Medicine, Rabat, Morocco Email: hakimi.fatiha@gmail.com

Received: 17 Dec 2021; Received in revised form: 01 Feb 2022; Accepted: 09 Feb 2022; Available online: 19 Feb 2022 C) 2022 The Author(s). Published by Infogain Publication. This is an open access article under the CC BY license (https://creativecommons.org/licenses/by/4.0/).

\begin{abstract}
A characterization based on agricultural practices was carried out using surveys of 50 farmers in six agricultural zones in peri-urban area of Casablanca in Morocco. The objective was to assess the potential of peri-urban farms for transition towards more ecological production methods. The study revealed that $96 \%$ of farmers use chemical inputs, only two of them adopt organic or agroecological production methods and $14 \%$ of respondents plan to convert to organic farming. The typology allowed deducing that peri-urban farms are medium to large (> $3 \mathrm{ha}$ ), mostly family-owned and $24 \%$ of them adopt subsistence farming (vegetable crops, cereals, leguminous and fruit trees). All farms have common strengths, such as the widespread practice of crop rotation and associations and organic fertilization. Thus, they are playing a major role in environmental management by recycling livestock products in form of organic manure and by using crop compost for soil maintenance. However, farms are facing global challenges in terms of the significant expansion of urban spaces, insufficient and high cost of agricultural labor, lack of technical support and water shortage. But also, specific challenges in terms of use of synthetic pesticides and sustainable fertilization for an agroecological transition. Producers are unaware about the effects of their practices on the environment, especially in peri-urban areas where technical support is insufficient and awareness of health and environmental impacts of agricultural practices needs to be consolidated.
\end{abstract}

Keywords-Agroecology, Environment, Food security, Peri-urban agriculture, Sustainability, Typology.

\section{INTRODUCTION}

Urbanization is a global phenomenon that is changing living conditions and environments on all continents [1]. This is due to rural exodus and urban population growth. The spatiotemporal process of urbanization occurs in different ways and varies from one country to another and between the cities. Several areas, known originally for their agricultural production, have become today large cities in full expansion and development. Nowadays, these growing cities are expanding and encroaching onto nearby fertile agricultural [2, 3, 4, 5].

Most cities face population growth and urban sprawl, leading to high agricultural land consumption, increased food demand, unemployment and environmental pollution. This urbanization was accompanied by the emergence of peri-urban agriculture, appearing on the fringes of cities. The development of the metropolis has profoundly changed the territory. The intersection of the two worlds, rural and urban, creates a third space: the peri-urban.

Peri-urban agriculture in the metropolis of Casablanca is considered as agriculture located on the outskirts of the city. It processes and distributes a range of food products to meet the needs of the urban population, using the human and natural resources, products and services present in and around this urban area. This kind of agriculture includes various speculations (vegetable crops, cereals, arboriculture, fodder crops, livestock, ...) and offers several 
functions (food, socio-economic and environmental) while being confronted with numerous constraints (rapid urbanization, slums pressure, land insecurity, shortage and high cost of agricultural labor, lack of technical support for farmers and water supply shortage, ...).

Nowadays, agriculture in general, and peri-urban farming in particular, have to face many challenges mainly the increase in food supply, but also the requirement of agricultural production guaranteeing food safety, nutritional quality and respect for the environment [6]. However, in many developing countries, regulations of production techniques or the sanitary quality of agricultural production are either non-existent or are not accompanied by effective control of practices, inputs and food products. Thus, agricultural production is often based on an intensive, even excessive, use of inputs (mineral fertilizers, phytosanitary products, water and energy), with often harmful consequences for human health and environment [7, 8]. Faced with these threats, many initiatives are emerging to promote agricultural practices that are more respectful of human health and environment $[9,10,11,12]$, both in terms of crop fertilization, pests and diseases biocontrol, water quality, and crop diversity. These initiatives are part of a more effective approach to promote sustainable agricultural production, preferably organic, even agroecological $[13,14,15]$.

In this study, farms on the outskirts of the city of Casablanca in Morocco are used as a case study because of their diversity inducing differences in access to water and inputs, but also in access to land or markets.

According to several authors $[16,17,18]$, the age and level of education of farmers, but also the mode of access to land and natural resources are all factors behind the diversity of agricultural exploitations.

However, it is well established that taking this diversity into account is an essential condition for improving the effectiveness of the interventions of development actors with farmers [19]. Thus, in order to better guide farmers towards an agroecological transition, the aims of this study were to characterize current production practices according to the production environment, to understand the logic that guides the choice of these practices, to analyze the producer's perception of the impact of their practices and identify the obstacles to the adoption of more ecological practices. Given the great diversity of farms on the fringes of the metropolis of Casablanca, this multifunctional and multi-criteria characterization of cropping systems could serve as a basis for planning information, training and popularization actions on agroecological practices by development actors in the years to come.

\section{MATERIAL AND METHODS}

\subsection{Study area}

The study is centered on the outskirts of the metropolis of Casablanca, the first city in the country, with an annual rainfall of $350 \mathrm{~mm}$ [20]. Six study areas were chosen within a radius of $40 \mathrm{~km}$ from the center of the metropolis, in order to cover all the speculation practiced in the region (Fig.1).

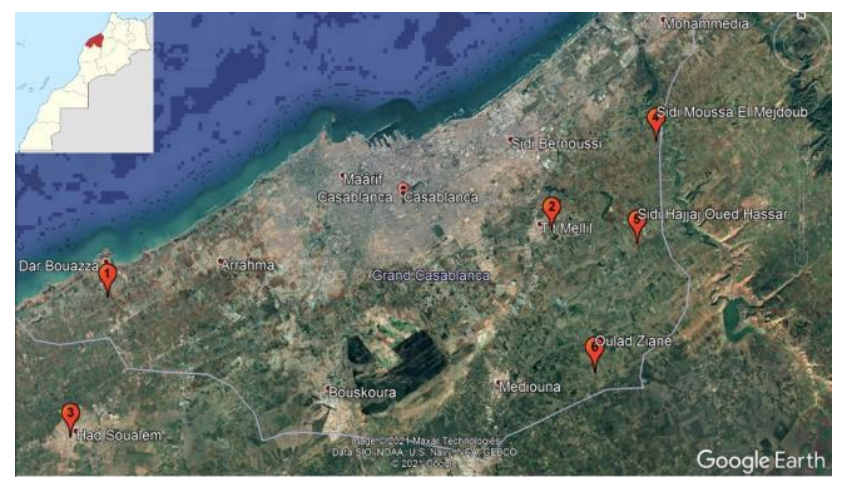

Fig.1: Geographical location of study sites in the outskirts of Casablanca metropolis (Google Earth, image of May 2021).

\subsection{Farm sampling and interviews}

The choice of farms was made according to several criteria namely their location from the city, the motivation and willingness of farmers to participate in surveys and the main speculation practiced.

The choice and identification of these farms were made in advance by field visits. Thus, a sample of 50 farms was selected to extract representative data of the study area (Fig.2). The study was based on the analysis of the bibliographical collection of several years, old and recent photos and maps. It was also based on a series of interviews and surveys carried out with farmers operating in the peri-urban areas of the metropolis.

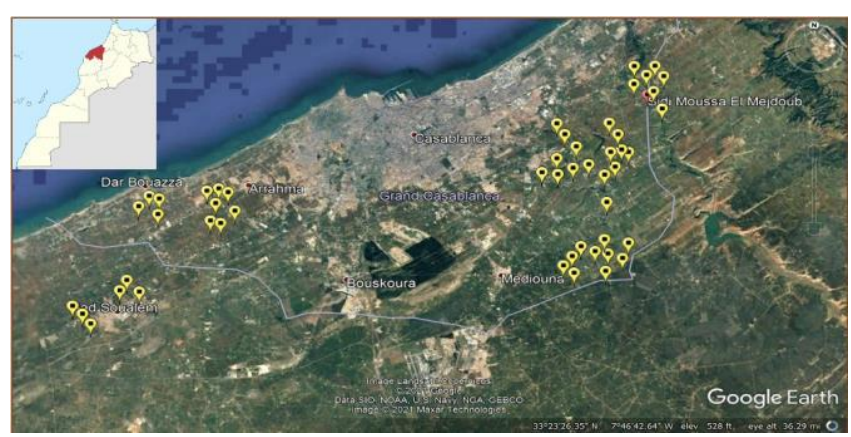

Fig.2: Map representing the location of the different farms (Google Earth, image of May 2021) 


\subsection{Data collection}

To collect the needed data and to facilitate field surveys, a questionnaire of 85 questions was developed and administered to fifty respondents.

The questionnaire was structured in five parts: general characteristics of the farm and production systems; the methods of crops management, organization of work and use of inputs within peri-urban farms and the willingness of farmers to convert to organic or agroecological production systems; farmers' expenses and income; the product marketing channels and the difficulties and constraints encountered by farmers and their suggestions for improving working conditions.

\subsection{Statistical Analysis}

Data used in analysis were systematically organized, summarized, processed and interpreted using appropriate data analysis techniques to make them meaningful and to draw sound conclusion based on the research findings. The data collected through questionnaire are quantitatively tabulated, interpreted and presented by using statistical methods such as frequency distribution, Chi-square test, Tests of normality and homogeneity of variances, means comparison test and Principal component analysis (PCA) were used for the analysis of the data collected. Descriptive statistics were processed using the statistical software package SPSS version 26 (Statistical Package of Social Sciences, V26.0) and MS Excel. In the following sections we provide some key descriptive results.

\section{RESULTS AND DISCUSSION}

\subsection{Household and peri-urban farms characteristics}

The study revealed that $40 \%$ of the farmers are between 51 and 60 years and 34\% are above 61 years. This result indicates that more than $74 \%$ of the respondents fall within the range of 51 years and above, suggesting that the majority of the farmers belong to the elderly population.

According to the results, $17.30 \%$ of the surveyed population practice peri-urban agriculture for its profitability and $56 \%$ of farmers practice it because of poverty and unemployment. The data suggest an extremely low level of education among farming households, as most of them have not exceed secondary education level. The results show that the majority of agriculturalists $(44 \%)$ had farm sizes bigger than 5 ha. The class of small family farms occupying less than 3 ha also has a significant proportion, i.e., $34 \%$ of the farms surveyed. The survey result indicates that about $64 \%$ inherited the land they were using, $8 \%$ bought the land, while $28 \%$ rented it. Similarly, Bellwood-Howard et al. [21] describe peri-urban farms in
West Africa as small ones. The majority of land has hitherto been customarily owned by the traditional authorities in trust for the people or belongs to the state and $62 \%$ of surveyed agriculturalists have not received any formal school education. In Tunis, a study performed by Hammami and Sai [22], showed that farmers in peri-urban areas of the city follow different strategies in their production. The authors have identified two major types of farms: An intensive and dynamic agricultural system practiced in farms that do not exceed 4.5 ha and a more diversified and intensive system that is practiced in larger farms.

\subsection{Typology of cropping practices and agricultural systems}

In Casablanca, peri-urban agriculture is characterized by a great diversity of cultivated crops (vegetable crops, cereals, leguminous, fruit trees, ...). According to the major finding of the study, crop rotation and associations are practiced by all peri-urban producers in the metropolis. The types of association and rotation adopted are very diverse and vary from one area to another (Fig.3).

About $34 \%$ of the total production in surveyed farms is intended for commercialization in local markets within short and direct circuits. Food crops represent $24 \%$ and are mainly fodder crops intended for animal feed. Both cash and food crops are mainly vegetable crops, field crops and arboriculture (Fig.4). In France, horticulture, arboriculture, vegetable crops, and equine production are the most common crops in urban centers. The remoteness of the city determines the choice of culture and the size of the farms. The peri-urban areas closer to the city are characterized by small intensive farms [23]. Similar findings were found by Maachou and Otmane [24] in the peri-urban agricultural landscape of Oran in Algeria, where a diverse range of seasonal, off-season and perennial crops is present. This diversification has increased through the use of modern irrigation systems. In the outskirts of Oran, farms combine several vegetable crops namely seasonal species (peas, beans, etc.) or speculative crops (watermelon, melon), while others have specialized in fast-moving products such as spinach and aromatic plants. The size of cultivated plots varies between 1 and 3 hectares on average and both forms of land tenure, direct and indirect. 


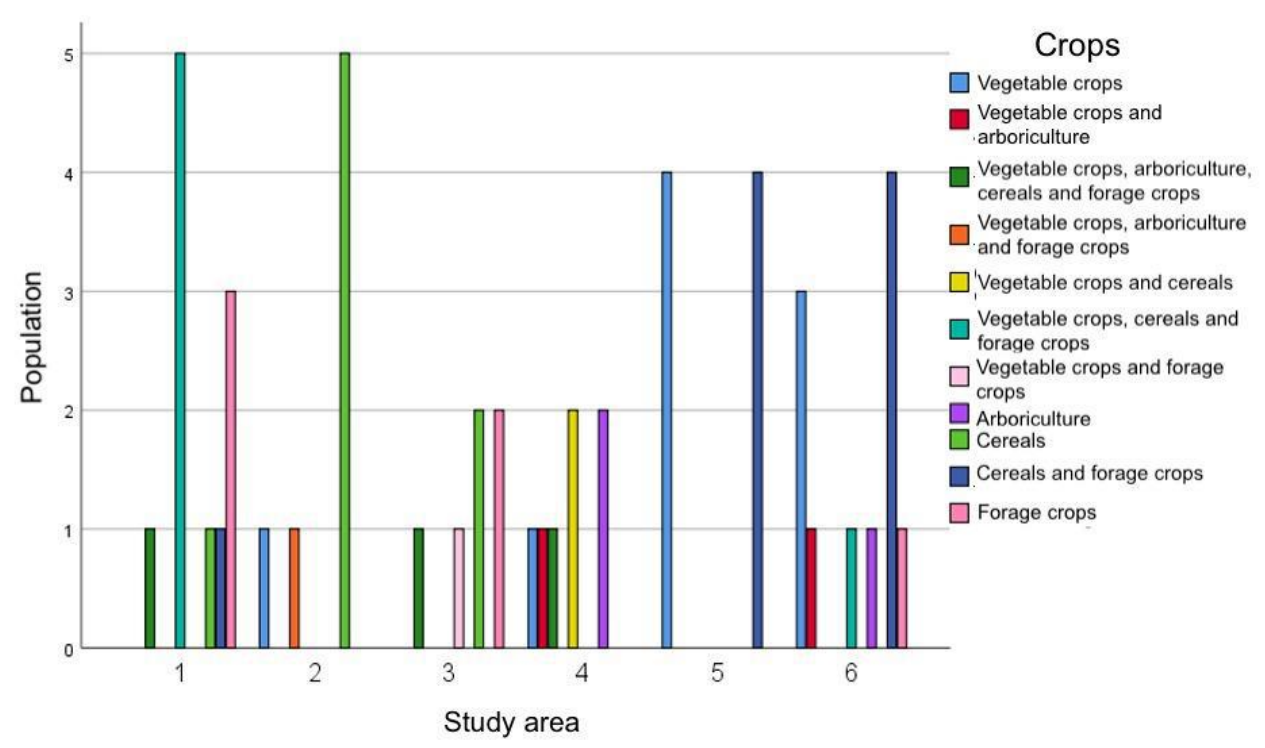

Fig.3: Types of crops practiced by peri-urban farmers in the six study areas

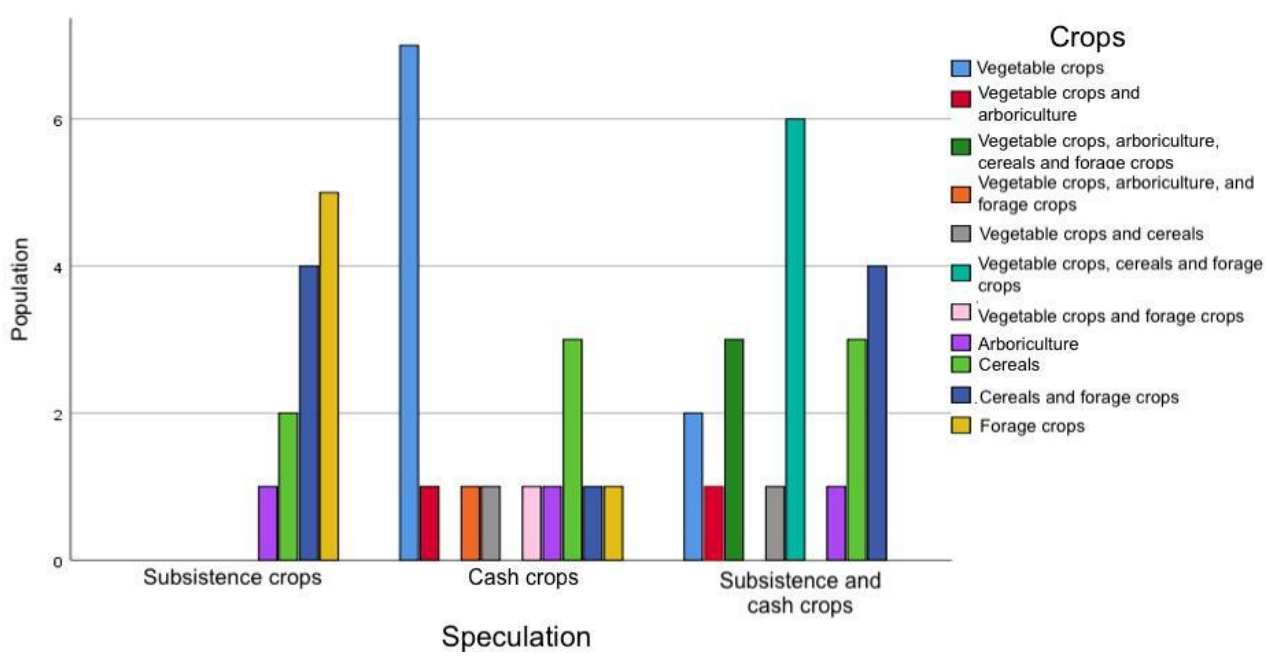

Fig.4: Crops grown in the six study areas according to their final destination

It is observed that livestock is traditionally practiced by $62 \%$ of respondents, namely beef and sheep farming. Results of the survey indicate that irrigation is practiced by $74 \%$ of farmers while the remaining $26 \%$ adopt a rain-fed agriculture. In a study by Daburon et al. [25], the metropolis of Cairo is characterized by family agriculture of polyculture-livestock which is located in urban and periurban areas. It mainly develops on the entrance to the Nile delta. Family farms are divided into two main types: integrated polyculture farms (cereals, fodder, market gardening) and animal husbandry (dairy buffaloes, beef cattle and fattening with cows of the local "Baladi" breed) and farms dedicated to dairy production. Alongside is developing intensive agriculture, which is both specialized in local and export products.
In the metropolis of Casablanca, the overwhelming majority of surveyed farmers $(96 \%)$ use chemical inputs and phytosanitary products in the production process and only two farmers practice organic farming. The use of fertilizers, whether chemical or organic, is very popular in peri-urban agriculture in order to resist diseases, strengthen plant growth and obtain good yields. Chemical fertilizers (33.5\% ammonium nitrate, $46 \%$ urea, N-P-K compound fertilizers, etc.) are used by $90 \%$ of the surveyed farmers. According to the results, $84 \%$ of respondents use phytosanitary treatments in the agricultural production process including insecticides, herbicides and fungicides (Fig.5). 


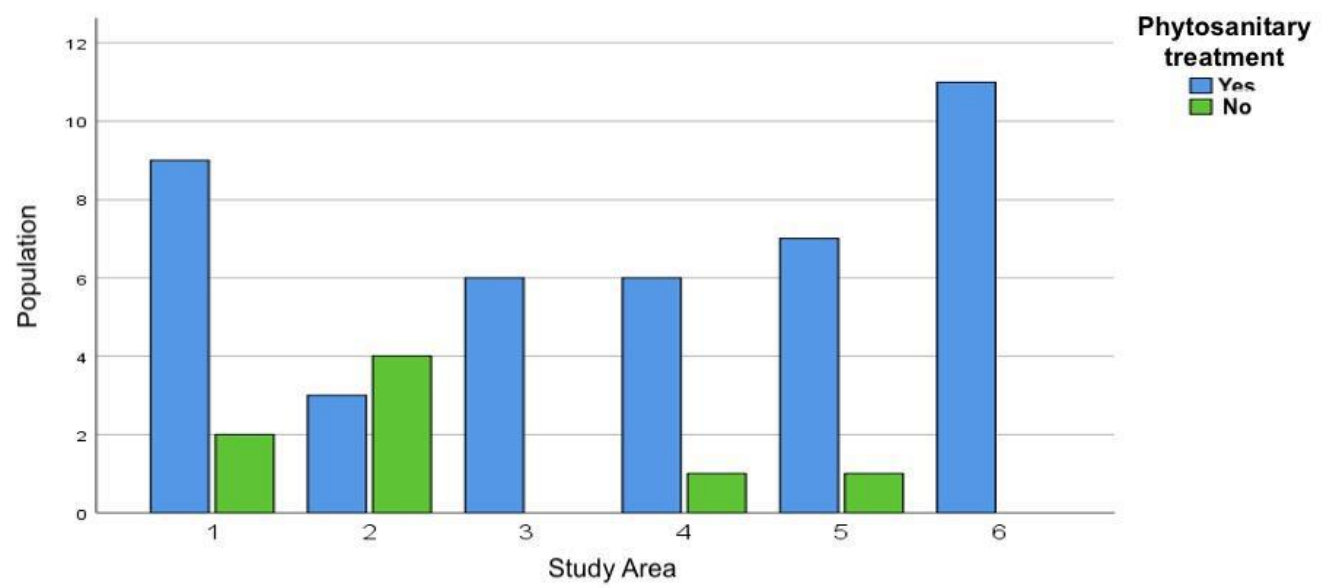

Fig.5: Frequency of use of phytosanitary treatments according to the study area

The study revealed also that the practice of organic agriculture is almost absent in the metropolis of Casablanca for reasons generally related to production costs, higher labor requirements and lower yields than conventional agriculture. Only $14 \%$ of respondents plan to convert to organic farming while $86 \%$ of farmers prefer to continue to manage their plots in conventional.

\subsection{Environmental impact of peri-urban agriculture in the metropolis}

Faced with the numerous losses caused by the damage of parasites and diseases, the use of phytosanitary products (insecticides, fungicides and herbicides) is very popular among farmers in the metropolis of Casablanca. By using synthetic chemical pesticides, producers aim to guarantee the physical appearance and profitability of crops whose production costs are high [26]. This use is intensive and irrational, the doses and application dates of the products are not respected by the farmers, hence the contamination of the various components of the environment and consequently the threat to human health. These results were similar to Son et al. [27] who reported that the low level of education of producers causes a lack of knowledge of the main crop enemies and difficulties in reading the methods of use of pesticides appearing on the packaging, thus leading to excessive and sometimes inappropriate use of the phytosanitary products. In addition, the poor knowledge of cultivated areas makes the calculation of doses difficult especially for those who are not literate.

The survey result reveals that the soils of the perimeters irrigated by the river «Oued El Malleh » in the area of Sidi Moussa El Mejdoub, suffer from a serious problem of salinization. Uncontrolled irrigation with salt water concentrates the salts on the surface without being able to wash them away since the drainage is insufficient. This salinity limits the diversification of crops in the area, decreases yields and threatens the sustainability of agriculture on the fringes of the metropolis. According to the major findings of the study, many farmers in the six study zones are also facing irrigation water supply problems due to the scarcity of water resources and the lowering of the water table. The results were the same as those of Hakimi [6] who concluded that the main constraint behind the regression of peri-urban farms on the fringes of the capital of Morocco is the shortage of water.

All Farmers in the metropolis of Casablanca use livestock waste in their production. The use of organic manure, either with plowing or by simple spreading, has several advantages such as the reduction of nitrogen losses and the improvement of soil fertility which allows to increase crops yield. Almost all growers claim that it has a beneficial effect on the soil and the different crops. According to the study, all peri-urban producers believe that organic manure has no effect on the quality of groundwater and surface water. Temple and Moustier [28], Compaoré and Nanéma [29], Houot et al. [30], Kakai et al. [31] and Tounkara [32] reported similar findings.

\section{CONCLUSION AND RECOMMENDATIONS}

Despite the generalized use of synthetic pesticides and mineral fertilization by almost all the farmers, the practices of rotation and crop associations as well as organic fertilization implemented by the majority of them constitute an asset for initiating the agroecological transition of peri-urban cropping systems in the metropolis of Casablanca.

The characterization of peri-urban farms based on production practices has made it possible to define a certain number of challenges that peri-urban agriculture 
on the fringes of the metropolis should take up in order to succeed in its agroecological transition. The first challenge shared by all farms is the need to develop effective methods of integrated pest management. The use of organic products and predatory insects would be alternatives to adopt in order to reduce the use of chemical pesticides. The second challenge is the implementation of a reasoned management of the fertilization of crops and this through the reduction of the doses of fertilizers, especially those of nitrogen. In general, awareness of the health and environmental impacts of farming practices must be strengthened, among producers but above all among consumers, through whom a demand may emerge for products from farming systems that are more respectful of health and of the environment. Finally, this consumer awareness could also encourage the public authorities to more strictly enforce the laws in force regulating the use of pesticides and lead producers to modify their practices, allowing them a better economic valuation of their products from organic or agroecological farming systems.

\section{REFERENCES}

[1] H. B. N. Yongsi, Santé Urbaine: géo-épidémiologie des diarrhées infectieuses à Yaoundé. Editions Publibook, 2016.

[2] K. Asif (2014), Encroachment of agricultural land in urban fringe areas of Aligarh city, India-process and parameters, Asian Geographer, 31(2), pp. 129-148.

[3] S. Fazal (2000), Urban expansion and loss of agricultural land-a GIS based study of Saharanpur City, India. Environment and Urbanization, 12(2), pp. 133-149.

[4] T. M. Radwan, G. A. Blackburn, J. D. Whyatt \& P. M. Atkinson (2019), Dramatic loss of agricultural land due to urban expansion threatens food security in the Nile Delta, Egypt, Remote Sensing, 11(3), pp. 332.

[5] K. Shi, Y. Chen, B. Yu, T. Xu, L. Li, C. Huang, ... \& J. Wu (2016), Urban expansion and agricultural land loss in China: A multiscale perspective, Sustainability, 8(8), pp. 790.

[6] F. Hakimi (2021) Development potentials and sustainability challenges of peri-urban farming in the metropolis of Rabat (Morocco), Journal of Analytical Sciences and Applied Biotechnology, 3(2), pp. 3-2.

[7] A. Abdulkadir, P.A. Leffelaar, J.O. Agbenin, K.E. Giller, Nutrient flows and balances in urban and peri-urban agroecosystems of Kano, Nigeria. Nutrient Cycling in Agroecosystems, 95, pp 231-254, 2013.

[8] D. Tilman, K.G. Cassman, P. A. Matson, R. Naylor \& S. Polasky (2002), Agricultural sustainability and intensive production practices. Nature 418, pp. 671-677.

[9] A. Bagchi, B. C. Ghosh, D. K. Swain \& N. Bera (2015), Organic farming practice for quality improvement of tea and its anti-Parkinsonism effect on health defense, Journal of Physical Chemistry \& Biophysics 5(2).
[10] N. Hatcho, Y. Matsuno, K. Kochi, \& K. Nishishita (2012), Assessment of environment-friendly rice farming through life cycle assessment (LCA), Chiang Mai University Journal of Natural Sciences, 11, pp. 1-10.

[11] S. Novelli (2018), Determinants of environmentallyfriendly farming, Calitatea, 19(S1), pp. 340-346.

[12] N. Usio, Environmentally Friendly Farming in Japan: Introduction. In: Usio N., Miyashita T. (eds) SocialEcological Restoration in Paddy-Dominated Landscapes, Ecological Research Monographs. Springer, Tokyo, 2014.

[13] I. Darnhofer, Contributing to a Transition to Sustainability of Agri-Food Systems: Potentials and Pitfalls for Organic Farming. In: Bellon S., Penvern S. (eds) Organic Farming, Prototype for Sustainable Agricultures, Springer, Dordrecht, 2014.

[14] M. Vaarst, A. G. Escudero, M. J. Chappell, C. Brinkley, R. Nijbroek, N. A. Arraes \& N. Halberg (2018), Exploring the concept of agroecological food systems in a city-region context, Agroecology and Sustainable Food Systems, 42(6), pp. 686-711.

[15] A. Wezel, B. G. Herren, R. B. Kerr, E. Barrios, A. L. R. Gonçalves \& F. Sinclair (2020), Agroecological principles and elements and their implications for transitioning to sustainable food systems, A review of Agronomy for Sustainable Development. 40, pp. 40.

[16] F. Hakimi \& M. Brech (2020), Peri-Urban Agriculture in the Metropolitan Area of Rabat, Morocco: Potentials and Constraints, International Journal of Agriculture and Biological Sciences, 4 (6), pp. 76-82.

[17] S. Medawar, R. Daoud, D. Rutledge, \& N. Ouaini (2008). Impact économique de la pomoculture pour une agriculture durable en zone de montagne. New Medit, 7 (1), pp. 45-49.

[18] D. Sadi, L. Aziz \& A. Khatabi (2021), La petite agriculture marocaine: analyse des systèmes de production agricole de la commune rurale d'El Faid (Province de Taroudant), Revue Espace Géographique et Société Marocaine, 55, pp. $5-23$.

[19] M. Gafsi, Exploitations agricoles familiales en Afrique de l'Ouest et du Centre: Enjeux, caractéristiques et éléments de gestion. Editions Quae, 2007.

[20] L. El Ajhar, D. El Khachine, A. El Bakouri, K. El Kharrim, \& D. Belghyti (2018), Evolution de la pluviométrie de 1960 à 2015 au Maroc. International Journal of Research Science and Management, 5, pp 47-56.

[21] I. Bellwood-Howard, V. Haring, H. Karg, R. Roessler, J. Schlesinger \& M. Shakya. Characteristics of urban and peri-urban agriculture in West Africa: results of an exploratory survey conducted in Tamale, Ghana, and Ouagadougou, Burkina Faso. Colombo, Sri Lanka: International Water Management Institute (IWMI), 2015, pp.38.

[22] M. Hammami \& M. E. SAI (2008), Problèmes fonciers et agriculture périurbaine dans le grand Tunis: mutations foncières et stratégies des agricultures, New Medit, 7(1), pp. 58-64.

[23] C. Soulard \& B. Thareau (2009), Les exploitations agricoles péri-urbaines: diversité et logiques de développement. Innovations agronomiques, 5, pp. 27-40. 
[24] H. M. Maachou \& T. Otmane (2016), L'agriculture périurbaine à Oran (Algérie): diversification et stratégies d'adaptation, Cahiers Agricultures 25 (2).

[25] A. Daburon, V. Alary, A. Ahmed, M. El-Srogi \& J. F Tourrand. In: Bosc Pierre-Marie (ed.), Sourisseau JeanMichel (ed.), Bonnal Philippe (ed.), Gasselin Pierre (ed.), Valette Elodie (ed.), Bélières Jean-François (ed.), Diversité des agricultures familiales: Exister se transformer, devenir. Versailles: Ed. Quae, 2015, pp. 41-55.

[26] C. C. A. Ahouangninou, Durabilité de la production maraîchère au sud-Bénin: un essai de l'approche écosystémique. Thèse de Doctorat Unique. Bénin: Université d'Abomey-Calavi, pp. 344, 2013.

[27] D. Son, I, Somda, A, Legrève \& B. Schiffers (2017), Pratiques phytosanitaires des producteurs de tomates du Burkina Faso et risques pour la santé et l'environnement, Cahiers Agricultures 26, 25005.

[28] L. Temple \& P. Moustier (2004), Les fonctions et contraintes de l'agriculture périurbaine de quelques villes africaines (Yaoundé, Cotonou, Dakar), Cahiers Agricultures, 13 (1): pp. 15-22.

[29] E. Compaoré \& L. S. Nanéma, Compostage et qualité du compost de déchets urbains solides de la ville de BoboDioulasso, Burkina Faso. Tropicultura, 28(4), 2010, pp. 232-237.

[30] S. Houot, W. T. Kaboré, E. Hien, P. Zombré, A. Coulibaly \& D. Masse, Valorisation de substrats organiques divers dans l'agriculture péri-urbaine de Ouagadougou (Burkina Faso) pour l'amendement et la fertilisation des sols: acteurs et pratiques, 2011.

[31] H. F. Kakai, A. G. Kakai \& A. G. Tohouegnon, Agriculture urbaine et valorisation des déchets au Bénin: une approche de développement durable. 2010.

[32] S. Tounkara, La valorisation des déchets organiques dans l'agriculture "péri-urbaine" à Dakar (Sénégal): analyse d'une multifonctionnalité stratégique $[\mathrm{PhD}$ Thesis, University of Toulouse. France]. 2015. 